\author{
ANNALS OF THE \\ UNIVERSITY OF CRAIOVA
}

$\begin{aligned} \text { Series: } & \checkmark \text { Biology } \\ & \checkmark \text { Horticulture } \\ & \checkmark \text { Food products processing } \\ & \text { technology } \\ & \checkmark \text { Environmental engineering }\end{aligned}$

\title{
Vol. XXVI (LXII) - 2021 \\ THE REACTION OF SOME COWPEA GENOTYPES TO THE THERMOHYDRIC CONDITIONS FROM THE AREA OF SANDY SOILS IN THE SOUTH OF OLTENIA
}

\author{
Drăghici Reta ${ }^{1 *}$, Drăghici lulian ${ }^{1}$, Ciurescu Georgeta ${ }^{2}$, Matei Gheorghe ${ }^{3}$, \\ Paraschivu Mirela ${ }^{3}$, Croitoru Mihaela ${ }^{1}$, Paraschiv Alina Nicoleta ${ }^{1}$, \\ Băjenaru Maria Florentina1, Dima Milica1 ${ }^{1}$, Dragomir Mereanț Cristina ${ }^{1}$ \\ ${ }^{1}$ Research Development Station for Plant Culture on Sands, Dăbuleni, Călărași, Dolj, 207170, Romania \\ ${ }^{2}$ National Research \& Development Institute for Biology and Animal Nutrition (IBNA), Calea Bucuresti, \\ no. 1, Balotesti, Ilfov, 077015, Romania \\ ${ }^{3}$ University of Craiova, A.I.Cuza no.13, Craiova 200585, Romania \\ *Correspondence author. E-mail: retadraghici@yahoo.com
}

Keywords: cowpea, drought, physiology, foliar index, productivity

\begin{abstract}
This paper presents the results of research conducted in the period 2020-2021 on the cowpea crop, which aimed at the behavior of 4 genotypes under the termohydric conditions from the area of sandy soils in southern Oltenia. Under the study conditions, the vegetation period of the cowpea genotypes took place during 96-105 days, with a thermal requirement of 2162$2391^{\circ} \mathrm{C}$. From the point of view of the correlation of the physiological indices with the productivity of the plant, the cowpea variety Aura 26 behaved best, which at an average daily transpiration of $2.69 \mathrm{mmol} \mathrm{H} \mathrm{H}_{2} \mathrm{O} \mathrm{m}^{2} / \mathrm{s}$ and a leaf index of 8.05, assimilated by photosynthesis about $11.57 \mu \mathrm{mol} \mathrm{CO} 2 / \mathrm{m}^{2} / \mathrm{s}$ and recorded an average of 14.6 pods / plant with 8.9 grains / pod. The results obtained showed significant increases in grain production $(p>0.05)$ in all genotypes studied, compared to the control variety Jiana.
\end{abstract}

\section{INTRODUCTION}

The cowpea (Vigna unguiculata L. Walpers), native to Central Africa, is a plant with increased drought tolerance, with a wide ecological plasticity, being the main legume for grains for the population of Africa (Emongor, 2007). Having a deep root system, a waxy layer on the leaves and a good strategy to avoid dehydration of the foliar apparatus by closing the stomata, cowpea can capitalize on drought conditions with good results (Halilou et al., 2015, Munjonji et al., 2018 ). Cowpea, are also, an unpretentious plant in soil conditions and an important source of protein for climatically disadvantaged areas (Düzdemir et al., 2010, Matei et al., 2015), capitalizing on good results poor sandy soils (Gerrano et al., 2015). Being a leguminous plant, the cowpea forms on its roots numerous nodules, in which symbiotic bacteria of the genus Rhizobium develop, which fix the atmospheric nitrogen (Eliade et al., 1975). The process of biological nitrogen fixation has great significance, given the prospect of population growth, which requires increased production of cereals and legumes, productions that are made with very large amounts of chemical nitrogen fertilizers (Awonaike, 1990, Ndungu et al., 2018). Bacteria of the genus Rhisobium, which form in the nodules on the root of the 
cowpea plant have the ability to stimulate the reduction of the effects of stress on the environment, including drought (Oliveira et al., 2017).

\section{MATERIAL AND METHODS}

The researches were carried out at RDSPCS Dabuleni, in the period 20202021 , and aimed at the behavior of four genotypes of cowpea (Vigna unguiculata L. Walpers) in the thermohydric conditions in the area of sandy soils from the south of Oltenia. We studied three varieties of cowpea, created in Dăbuleni (Aura 26, Ofelia, Doljana), compared to the variety Jiana (control), created in Tâmburești. The experiment was organized by the method of randomized blocks, on a sandy soil with low natural fertility, poorly supplied with total nitrogen $(0.045-0.08 \%)$, medium to normal supplied with extractable phosphorus (41-87 ppm), reduced to medium supplied in exchangeable potassium (65-97 ppm) and with a weak acid soil reaction ( $\left.\mathrm{pH} \mathrm{H} \mathrm{H}_{2} \mathrm{O}=5.9-6.59\right)$, under irrigation conditions. During the vegetation period, determinations of biology, biometrics, physiology and plant productivity were performed, as well as the quality of production at harvest. Determinations of plant physiology (photosynthesis rate, foliar transpiration rate and stomatal conductance) were performed in the flowering phase of the plant using the LC Pro SD device. The leaf area was determined in the laboratory using the Area Metter AM 300 device, and at harvest was analyzed the quality of the cowpea (protein and fat) by the Perten method. The results were calculated and analyzed by the method of analysis of variance (ANOVA) and using mathematical functions.

\section{RESULTS AND DISCUSSIONS}

From the analysis of the climatic conditions registered during the cowpea vegetation period (Table 1), it was highlighted the accentuation of the drought phenomenon during the vegetation period, by increasing the air temperature compared to the multiannual average, which corroborated with the recorded precipitation, led to increased thermohydric stress. Thus, compared to the multiannual temperature, the average temperature during the study period increased by $1.1^{\circ} \mathrm{C}$, and the precipitations registered lower values by $39 \mathrm{~mm}$. The amount of $186.4 \mathrm{~mm}$ of precipitation registered during the vegetation period was insufficient, in relation to the requirements of the cowpea plant, being necessary the application of 3 waterings with norms of $250 \mathrm{~m}^{3}$ water / ha.

The results regarding the biometrics and the productivity of the plant showed differentiations according to genotype (Table 2). The Jiana variety has developed a rich vegetative mass, given the high values of plant height $(104.9 \mathrm{~cm})$ and leaf index (8.76), which is why it can be recommended for incorporation into the soil as a green fertilizer. The analysis of the productivity elements of the plant, highlighted the Aura 26 cowpea variety, by registering 14.6 pods / plant, with 8.9 grains / pod and $14 \mathrm{~cm}$ average length of the pod. From germination to the end of the vegetation period, all the vital processes of the plant took place in high temperature conditions, above $10^{\circ} \mathrm{C}$. Under the study conditions, the vegetation period of the cowpea genotypes took place during 96-105 days, with a thermal requirement of $2162-2391^{\circ} \mathrm{C}$. Compared to the Jiana variety, which is very late, the Aura 26 and Doljana genotypes were highlighted at an early age of 9 days. 
Table 1

Climatic conditions registered at the weather station of at RDSPCS Dăbuleni during the cowpea vegetation period

\begin{tabular}{|l|c|c|c|c|c|c|}
\hline \multicolumn{2}{|c|}{ Climatic conditions } & May & June & July & August & $\begin{array}{c}\text { Average }\left({ }^{\circ} \mathrm{C}\right) / \text { Sum } \\
(\mathrm{mm})\end{array}$ \\
\hline $\begin{array}{l}\text { Average temperature } \\
\left({ }^{\circ} \mathrm{C}\right)\end{array}$ & $2020 / 2021$ & 17.4 & 21.8 & 25.1 & 24.6 & 22.2 \\
\cline { 2 - 7 } & $1956-2021$ & 17.1 & 21.6 & 23.1 & 22.7 & 21.1 \\
\hline $\begin{array}{l}\text { Deviation }\left({ }^{\circ} \mathrm{C}\right) \text { from the } \\
\text { multiannual }\end{array}$ & 0.3 & 0.2 & 2.0 & 2.1 & 1.1 \\
\hline \multirow{2}{*}{ Ranfall (mm) } & $2020 / 2021$ & 57.1 & 54.4 & 44.9 & 30 & 186.4 \\
\cline { 2 - 7 } & $1956-2021$ & 62.7 & 70.2 & 55.4 & 32.6 & 220.9 \\
\hline $\begin{array}{l}\text { Deviation (mm) from the } \\
\text { multiannual }\end{array}$ & -5.6 & -15.8 & -10.5 & -2.6 & -39.0 \\
\hline
\end{tabular}

Table 2

Results regarding the value of some morphology, biology and productivity characters in some cowpea varieties

\begin{tabular}{|l|c|c|c|c|c|c|c|}
\hline $\begin{array}{c}\text { Cowpea } \\
\text { variety }\end{array}$ & $\begin{array}{c}\text { Plant } \\
\text { size } \\
(\mathrm{cm})\end{array}$ & $\begin{array}{c}\text { No } \\
\text { pods / } \\
\text { plant }\end{array}$ & $\begin{array}{c}\text { No. } \\
\text { grains / } \\
\text { pods }\end{array}$ & $\begin{array}{c}\text { Pod } \\
\text { length } \\
(\mathrm{cm})\end{array}$ & $\begin{array}{c}\text { Leaf } \\
\text { area } \\
\text { index }\end{array}$ & $\begin{array}{c}\text { Vegetation } \\
\text { period } \\
\text { days }\end{array}$ & $\begin{array}{c}\text { Thermal } \\
\text { resources } \\
\text { required }\left({ }^{\circ} \mathrm{C}\right)\end{array}$ \\
\hline Jiana & 104.9 & 8.5 & 8.8 & 13.9 & 8.76 & 105 & 2390.9 \\
\hline Aura 26 & 83.9 & 14.6 & 8.9 & 14 & 8.05 & 96 & 2165.8 \\
\hline Ofelia & 82.7 & 13.1 & 8.3 & 12.5 & 6.6 & 98 & 2204.3 \\
\hline Doljana & 69.2 & 12.0 & 8.7 & 13.1 & 5.78 & 96 & 2161.8 \\
\hline
\end{tabular}

The determinations regarding the physiology of the plant revealed a diurnal variation of the processes of photosynthesis and perspiration, the results being differentiated according to the climatic conditions of the year and varieties. (Table 3, Figure 1).

Table 3

Meteorological indices recorded in the LC Pro SD device at the time of cowpea physiological determinations

\begin{tabular}{|l|c|c|c|c|c|c|}
\hline \multicolumn{1}{|c|}{$\begin{array}{c}\text { Diurnal variation of } \\
\text { meteorological indices }\end{array}$} & \multicolumn{3}{|c|}{ Year 2020 } & \multicolumn{3}{c|}{ Year 2021 } \\
\cline { 2 - 7 } & $\begin{array}{c}9 \\
\text { o'clock }\end{array}$ & $\begin{array}{c}15 \\
\text { o'clock }\end{array}$ & $\begin{array}{c}9 \\
\text { o'clock } \\
\text { o'clock }\end{array}$ & $\begin{array}{c}12 \\
\text { o'clock }\end{array}$ & $\begin{array}{c}15 \\
\text { o'clock }\end{array}$ \\
\hline $\begin{array}{l}\text { Active solar radiation in } \\
\text { photosynthesis } \\
\left(\mu \mathrm{mol} / \mathrm{m}^{2} / \mathrm{s}\right)\end{array}$ & $\begin{array}{c}1640- \\
1660\end{array}$ & $\begin{array}{c}1826- \\
1884\end{array}$ & $\begin{array}{c}1874- \\
1887\end{array}$ & $\begin{array}{c}1290- \\
1318\end{array}$ & $\begin{array}{c}1710- \\
1720\end{array}$ & $\begin{array}{c}1573- \\
1760\end{array}$ \\
\hline Temperature $\left({ }^{\circ} \mathrm{C}\right)$ & $\begin{array}{c}27.6- \\
29.7\end{array}$ & $30-32$ & $35-35.4$ & $\begin{array}{c}32.8- \\
33.1\end{array}$ & $39.8-40$ & $\begin{array}{c}45.1- \\
46.4\end{array}$ \\
\hline $\begin{array}{l}\text { Atmospheric pressure } \\
(\mathrm{hPa})\end{array}$ & 1008 & 1008 & 1007 & 1009 & 1009 & 1007 \\
\hline
\end{tabular}

Temperatures above $35{ }^{\circ} \mathrm{C}$, which were recorded at the foliar level, intensified the thermohydric stress, the cowpea varieties reacting by reducing the photosynthesis process and intensifying the sweating process. Compared to 2020 , in 2021, when higher temperatures were recorded in the air, the daily accumulation 
rate of $\mathrm{CO}_{2}$ through the photosynthesis process was lower by $6.91 \mu \mathrm{mol} \mathrm{CO} / 2 \mathrm{~m}^{2} / \mathrm{s}$, and water losses through sweating were also lower by $0.72 \mathrm{mmol} \mathrm{H} 2 \mathrm{O} / \mathrm{m}^{2} / \mathrm{s}$ due to stomatal closure Due to the plant's biological properties, increased drought resistance and low soil fertility requirements, cowpea can be a good alternative to bean and soybean crops, which are very sensitive to stressors in areas with excessive drought (Drăghici, 2018, Gnankambary et. al., 2020). The degree of stomatal opening is an important indicator of the intensity of physiological processes in the cowpea plant (Munjonji et al., 2018). The positive effect of stomatal closure, resulting in the limitation of water loss from plants, also had a negative effect, by reducing the rate of penetration of carbon dioxide, necessary for the process of photosynthesis.

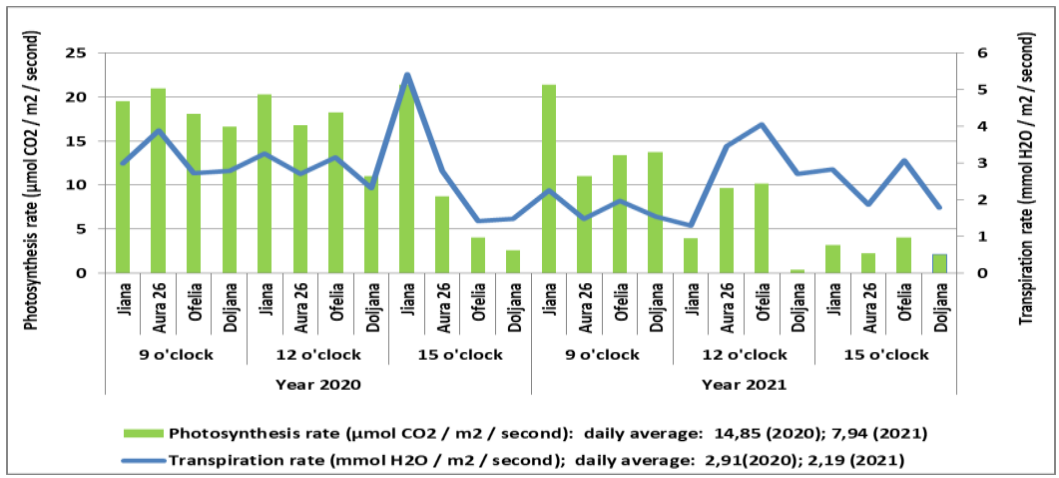

Figure 1. Diurnal variation of photosynthesis and transpiration processes recorded in some cowpea varieties in the period 2020-2021

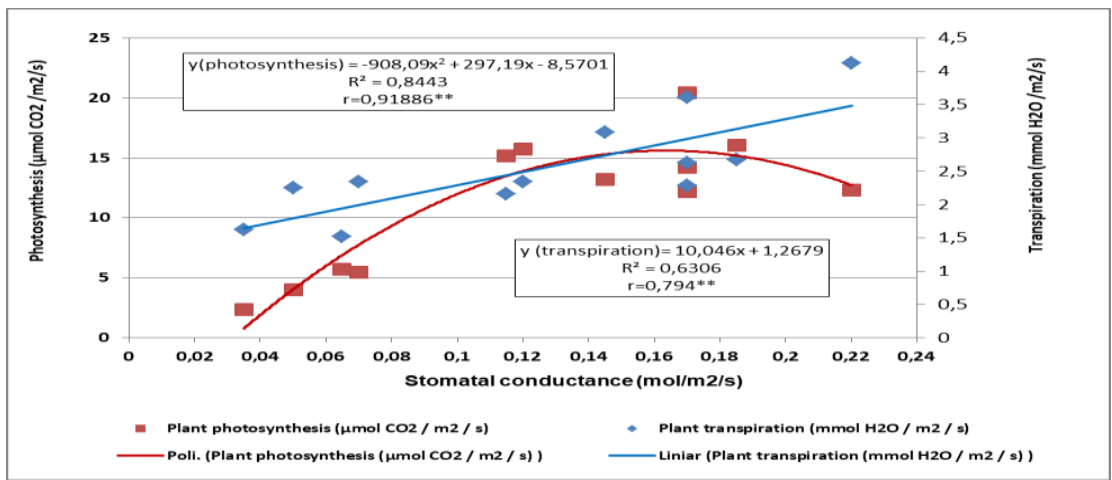

Figure 2. Correlation between stomatal conductance and transpiration and photosynthesis processes registered to some varieties of cowpea

Thus, at low values of stomatal conductance both transpiration and photosynthesis were reduced. The analysis of the functional link between the stomatal conductance and the photosynthesis process (average 2020-2021) is presented by the polynomial function of degree $2\left(r=-0.9189{ }^{* *}\right)$, which shows an intensification of $\mathrm{CO}_{2}$ accumulation at a stomata opening of maximum $0.16 \mathrm{~mol} / \mathrm{m}^{2}$ / $\mathrm{s}$, after which the rate photosynthesis is reduced (Figure 2). Stomach conductance was distinctly positively correlated with transpiration rate $\left(r=0.794{ }^{* *}\right)$. The results 
obtained at harvest have relevant yields between $1607.1-2797.6 \mathrm{~kg} / \mathrm{ha}$ of grains, depending on the variety (Table 4). Compared to the Jiana variety, taken as a control, the varieties Aura 26 and Ofelia were highlighted by production increases of 1019.9$1190.5 \mathrm{~kg} / \mathrm{ha}$, statistically assured as distinctly significant. Analysis of the nutritional quality of grains in some bean genotypes (Table 4) highlighted a protein content of $21.7-22.4 \%$ and a fat content of $3.1-4.2 \%$. The Aura 26 variety was highlighted, which achieved the highest amount of protein per unit area $(626.7 \mathrm{~kg} / \mathrm{ha})$.

Table 4

Production results obtained for some cowpea varieties in the period 2020-2021

\begin{tabular}{|l|c|c|c|c|c|c|c|}
\hline \multirow{2}{*}{$\begin{array}{c}\text { Cowpea } \\
\text { variety }\end{array}$} & \multicolumn{2}{|c|}{ Grain yield } & \multicolumn{2}{c|}{$\begin{array}{c}\text { The difference compared to the } \\
\text { control }\end{array}$} & \multicolumn{2}{c|}{ Quality } & $\begin{array}{c}\text { Protein } \\
(\mathrm{kg} / \mathrm{ha})\end{array}$ \\
\cline { 2 - 9 } & $(\mathrm{Kg} / \mathrm{ha})$ & $(\%)$ & $(\mathrm{Kg} / \mathrm{ha})$ & The significance & $\begin{array}{c}\text { Protein } \\
(\%)\end{array}$ & $\begin{array}{c}\text { Fats } \\
(\%)\end{array}$ & \\
\hline Jiana & 1607.1 & 100.0 & Control & Control & 22 & 4.2 & 353.6 \\
\hline Aura 26 & 2797.6 & 174.1 & 1190.5 & $* *$ & 22.4 & 3.6 & 626.7 \\
\hline Ofelia & 2627 & 163.5 & 1019.9 & $* *$ & 21.7 & 3.1 & 570.1 \\
\hline Doljana & 2297.6 & 143 & 690.5 & $*$ & 21.5 & 3.5 & 494.0 \\
\hline
\end{tabular}

LSD 5\% =669.6 kg/ha; LSD 1\% = $1014.0 \mathrm{~kg} / \mathrm{ha} ;$ LSD $0.1 \%=1629.0 \mathrm{~kg} / \mathrm{ha}$

\section{CONCLUSIONS}

Under the study conditions, the vegetation period of the cowpea varieties took place during $96-105$ days, with a thermal requirement of $2162-2391{ }^{\circ} \mathrm{C}$, highlighting the varieties Aura 26 and Doljana through an earlyness of 9 days, compared to Jiana variety (control).

From the point of view of the correlation of the physiological indices with the productivity of the plant, the cowpea variety Aura 26 behaved best, which at an average daily transpiration of $2.69 \mathrm{mmol} \mathrm{H}_{2} \mathrm{O} / \mathrm{m}^{2} / \mathrm{s}$ and a leaf index of 8.05 , assimilated by photosynthesis about $11.57 \mu \mathrm{mol} \mathrm{CO}_{2} / \mathrm{m}^{2} / \mathrm{s}$ and recorded a production of $2797.6 \mathrm{~kg} / \mathrm{ha}$.

The results obtained showed significant increases in grain production $(p>$ 0.05 ) in all cowpea genotypes studied, compared to the control variety (Jiana), which recorded a high value of the leaf surface index.

\section{ACKNOWLEDGMENT}

This research was financed by the Bucharest Ministry of Agriculture and Rural Development, through the Sectoral Program ADER 2022, Contract no. 1.4.2 I 27.09.2019.

\section{REFERENCES}

Awonaike K.O., Kumarasinghe K.S., Danso S.K.A., 1990. Nitrogen fixation and yield of cowpea (Vigna unguiculata) as influenced by cultivar and Bradyrhizobium strain, Field Crops Research. ISSN: 0378-4290, Volume 24, Issues 3-4, October, Nigeria, 1990, pp.163-171.

Draghici Reta, 2018. Cowpea-plant of sandy soils. Sitech Publishing House, Craiova. ISBN 978-606-11-6587-2.

Düzdemir O., Ünlükara A. \& Kurunç A., 2010. Response of cowpea (Vigna unguiculata) to salinity and irrigation regimes. New Zealand Journal of Crop 
andHorticultural Science. ISSN: 0114-0671 (Print) 1175-8783 (Online). 37:3, 271280, DOI: 10.1080/01140670909510273, Turcia.

Eliade Gh., Ghinea L., Ștefanic Gh., 1975. Soil microbiology. Edit. Ceres, Bucharest.

Emongor V., 2007. Gibberellic acid (GA3) influence on vegetative growth, nodulation and yield of cowpea (Vigna unguiculata (L.) Walp.). Journal of Agronomy Volume 6; Issue; eISSN: 1812-5417; p ISSN: 1812-5379, Botswana, 2007, pp. 509517.

Gerrano A.S., Adebola P.O., Jansen van Rensburg W.S. \& Sunette M.L., 2015. Genetic variability in cowpea (Vigna unguiculata (L.)Walp.) genotypes. South African Journal of Plant and Soil, Volume 32, 2015 - Issue 3, DOI: 10.1080/02571862.2015.1014435, Online ISSN: 2167-034X, South Africa, 2015, pp. 165-174.

Gnankambary K., Sawadogo N., Diéni Z., Batieno T.B.J., Tignegré J., Sawadogo M. and Ouédraogo T.J., 2020. Assessment of Cowpea (Vigna unguiculata (L.) Walp.) Mutant Lines for Drought Tolerance. Hindawi International Journal of Agronomy Volume 2020, Article ID 8823498, 9 pages https://doi.org/10.1155/2020/8823498.

Halilou O. Hamidou F., Boulama K.T., Saadou M., Vincent V., 2015. Water use, transpiration efficiency and yield in cowpea (Vigna unguiculata) and peanut (Arachis hypogaea) across water regimes. Crop and Pasture Science 66(7), 715-728. DOI: $10.1071 /$ CP14182.

Matei G., Soare M., Dodocioiu A., Boruz S., Cojocaru I., 2015. Cowpea (Vigna unguiculata $\mathrm{L}$. Walp) a valuable crop for drought areas with sandy soils. SGEM, Book Series: International Multidisciplinary Scientific GeoConference-SGEM. 15th International Multidisciplinary Scientific Geoconference (SGEM), Location: Albena, BULGARIA, JUN 18-24, 2015. 000371601900052ISBN_978-619-7105-42-1ISSN_ 1314-2704W, Pages: 381-388.

Munjonji L., Ayisi K.K., Boeckx P. and Haesaert G., 2018. Stomatal Behavior of Cowpea Genotypes Grown Under Varying Moisture Levels, Sustainability 2018, 10(1), 12; https://doi.org/10.3390/su10010012.

Ndungu S.M., Messmer M., Ziegler D., Gamper H.A., Mészáros E., Thuita M., Vanlauwe B., Frossard E., Thonar C., 2018. Cowpea (Vigna unguiculata L. Walp) hosts several widespread bradyrhizobial root nodule symbionts across contrasting agro-ecological production areas in Kenya. Agriculture, Ecosystems \& Environment, Volume 261, 1 July 2018, Pages 161-171, https://doi.org/10.1016/j.agee.2017.12.014.

Oliveira R.S., Carvalho P., Marques G., Ferreira L., Pereira S., Nunes M., Rocha I., Ma Y., Carvalho M.F., Vosátka M., Freitas H., 2017. Improved grain yield of cowpea (Vigna unguiculata) under water deficit after inoculation with Bradyrhizobium elkanii and Rhizophagus irregularis. Crop and Pasture Science, 68(10-11):10521059 (2017). https://doi.org/10.1071/CP17087. 